\title{
Soil Cover Dynamics in Semi-Arid Coniferous Forests of the Southern Israel
}

\author{
Sprintsin $\mathbf{S M}^{1,3 *}$ and Shapiro $\mathbf{M}^{2}$ \\ ${ }^{1}$ EIG group, forest department, Israel \\ ${ }^{2}$ The Ministry of Agriculture and Rural Development of Israel, Israel \\ ${ }^{3}$ Forestry Department, Jewish National Fund, Israel
}

Submission: April 03, 2018; Published: June 20, 2018

*Corresponding author: Sprintsin SM, Forestry Department, Jewish National Fund, Israel, Email: prin@zahav.net.il

Keywords: Soil cover; Semi-Arid; Coniferous forests; Pinus halepensis; Aleppo pine; Anthropogenically

\section{Opinion}

The conifer forests from Aleppo Pine (Pinus halepensis) of the southern part of Israel (the southern part of the Hebron Highlands) have been artificially planted 50-60 years ago over vast areas of anthropogenically deserted stony wastelands. These areas are characterized by semi-arid climate with an average annual precipitation of $270-290 \mathrm{~mm}$ and an average annual evaporatranspiration of $1600-1800 \mathrm{~mm}$.

Soils of the wastelands are desert stony lithosols which have a light brown profile with a total thickness of about $5-15 \mathrm{~cm}$ and in some places is covered with a very thin $(1-2 \mathrm{~mm})$ silty crust. The profile is poorly stony humus-accumulative horizon A1 with a humus content of $1-3 \%$ and transitional stony $\mathrm{A} 1 \mathrm{C}$ horizon with a humus content of $1-2 \%$. A1C horizon is located above the horizon $\mathrm{R}$ that is full of hard bedrock (limestone, dolomite and chalk) fragments. Before the planting activities have been started the lithosols have been dominated on the watersheds and slopes of the Hebron Highlands hills.

Along with the development of pine plantations and the maturation of the forests there was a reduction of the lithosols. Instead the lithosols the spots of light rendzinas have begun to form in the immediate vicinity to the tree trunks. Currently, the total thickness of the rendzinas is about $20-25 \mathrm{~cm}$. Its upper horizon (horizon 0 ) is represented by a $2 \mathrm{~cm}$ plant litter (mainly pine needles). Below it a $1-2 \mathrm{~cm}$ thick fragmentary rough humus $\mathrm{AO}$ or AO (A1) horizon is developed. It consists of different flakes of organic matter that has lost its original form. Below it lies dark gray humus-accumulation horizon A1 of $4-6 \mathrm{~cm}$ in thickness with a silt loam texture, a perfect granular structure, a humus content of $2-4 \%$ and small amount of stones. This horizon gradually turns into a gray-brown $\mathrm{A} 1 \mathrm{C}$ horizon - fine textured (silt loam)-stony with subangular structure, a humus content of about $2 \%$ and a thickness of about $8-10 \mathrm{~cm}$. It overlays a light brown colored, stony $\mathrm{C}$ horizon, which is non-structured, with a humus content of less than $1-2 \%$ and about $8 \mathrm{~cm}$ in thickness. Under it is revealed horizon $\mathrm{R}$ which is similar to the same one of the lithosols.

The fundamental difference between the lithosols and the rendzinas is determined by both the type of the profiles and the ecological role that they play in the landscape. The lithosols are the soils with a very simple profile incapable adsorbing and accumulating a significant amount of rainwater and runoff. The major part of the precipitation does not remain on the hill slopes, but rather discharged into the trans-accumulative landscape positions (local valleys). As a result, the lithosols that are formed on the slopes have a trend to be eroded and dissected giving way to appearance of rock outcrops. As consequence of the profile simplicity, the lithosols are very quickly (within only a few years) formed, and while disappearing in one place appear in the other. Under current semi-arid conditions the lithosols present natural and constant components of the soil cover of hilly regions.

In contrast to the lithosols, the rendzinas play quite a different role in landscape of the Southern Israel. Under the modern climatic conditions the genesis of these soils is heavily influenced by pine trees. To some extent pines create for themselves the most suitable soil environment, acting as a very active and successful builder of specific soil profiles. The main features of the rendzinas are their ability to accumulate atmospheric moisture and protect the pine roots from overheating. These are two extremely important soil features that support pines in very dry and hot conditions. They are achieved due to a presence of top-soil horizons such as $\mathrm{O}, \mathrm{AO}, \mathrm{AOA} 1$ and A1. According to 
our assessment, formation of the developed rendzinas requires approximately 50-60 years. At spaces between the pines, where the impact of the trees remains to be minimal, the lithosols still dominate in soil cover. The soil cover of the 50-60 years old forests only partially discharges the atmospheric and runoff moisture to the local valleys. A significant part of this moisture is adsorbed by the rendzinas and is used for feeding the trees during the dry spells. Consequently, a new type of hydrological landscape status is formed. This landscape is much more resistant to water erosion and is not a subject to uncontrolled destruction by runoff as compared to treeless lithosol landscapes.

Our work revealed that local spatial patterns of the rendzinous-lithosolic soil cover in the southern part of the Hebron Highlands depend on the aspect of the slope. There are two main types of these patterns. The first one is typical for "colder" northern slopes where the pines are spread evenly along the slope. In the same way rounded rendzinous spots of under the pine crowns are distributed along these slopes. The total ratio of the rendzinous and the lithosolic areas is about 4:6.
The second type of spatial pattern of the soil cover is typical for "hotter" southern slopes. On a time-scale the well-developed pines form clusters (curtains) separated from each other by relatively large distances. In accordance with this phenomenon the rendzinous spots are distributed heterogeneously along the southern slopes, remaining only within the groups of pines. The total ratio of the rendzinous and the lithosolic areas is about 3:7 or $2: 8$.

A very important feature of the pine forests of the semi-arid zone in Israel is the almost total absence of natural regeneration. Therefore, without any artificial renovation these forests may be a subject of age-related mortality. As it happens, the rendzinas will also disappear since, in contrast to the lithosols, they are unable to support themselves without pine presence in a landscape. Their place will be occupied once more by the lithosols and the rock outcrops. Only specially organized renovation of the modern pine forests may stop this negative process and prevent the desertification of the Hebron Highlands.

\section{Your next submission with Juniper Publishers will reach you the below assets}

- Quality Editorial service

- Swift Peer Review

- Reprints availability

- E-prints Service

- Manuscript Podcast for convenient understanding

- Global attainment for your research

- Manuscript accessibility in different formats

( Pdf, E-pub, Full Text, Audio)

- Unceasing customer service

Track the below URL for one-step submission https://juniperpublishers.com/online-submission.php 